\title{
Рост гетероструктур AlGaN:Si брегговских зеркал для спектрального диапазона, соответствующего зеленой люминесценции
}

\author{
И.В. Осинных ${ }^{1)}$, Т.В. Малин ${ }^{1)}$, Д.С. Милахин ${ }^{1)}$, И.А. Александров ${ }^{1)}$, К.С. Журавлев ${ }^{1)}$ \\ ${ }^{1}$ Институт физики полупроводников им. А.В. Ржанова СО РАН, \\ Новосибирск, 633090, пр. Ак. Лаврентьева, 13 \\ тел:+7 (383)330-44-75, факс:+7 (383)333-27-71, эл. почта: igor-osinnykh@isp.nsc.ru
}

DOI 10.34077/RCSP2019-123

Полупроводниковые лазеры синего и ближнего УФ диапазонов спектра на прямых оптических переходах между зоной проводимости и валентной зоной в активном слое активно используются во многих областях науки и техники. Однако продвижение в диапазон длин волн 500-550 нм, соответствующей максимальной чувствительности человеческого глаза, сопряжено с трудно решаемыми фундаментальными и технологическими проблемами. Альтернативным путем является использование оптических переходов через уровни дефектов в широкозонном (с регулируемой шириной запрещённой зоны в диапазоне $3.4-6.2$ эВ) твердом растворе $\mathrm{Al}_{\mathrm{x}} \mathrm{Ga}_{1-\mathrm{x}} \mathrm{N}$, сильно легированном донорами. Широкий спектр излучения дефектов в $\mathrm{Al}_{\mathrm{x}} \mathrm{Ga}_{1-\mathrm{x}} \mathrm{N}$ дает основание для создания источников света от сине-зеленого до ближнего инфракрасного диапазона спектра (практически весь видимый диапазон) и лазеров с уникальными параметрами - с перестраиваемой длиной волны в широком диапазоне длин волн и частот (до 500ТГц). Для исследования эффектов усиления спонтанного излучения и возможности получения лазерной генерации необходимы структуры с резонаторами. В предыдущих работах зеркалами резонатора являлись сколотые поверхности структуры. Распределённые брэгговские отражатели (брэгговские зеркала) позволяют отражать световые волны с гораздо более узкой полосой отражения и большим коэффициентом отражения, чем зеркала, полученные путём скола торцов лазеров. В данной работе представлены результаты роста гетероструктур AlGaN:Si с брегговскими зеркалами для спектрального диапазона, соответствующего зеленой люминесценции.

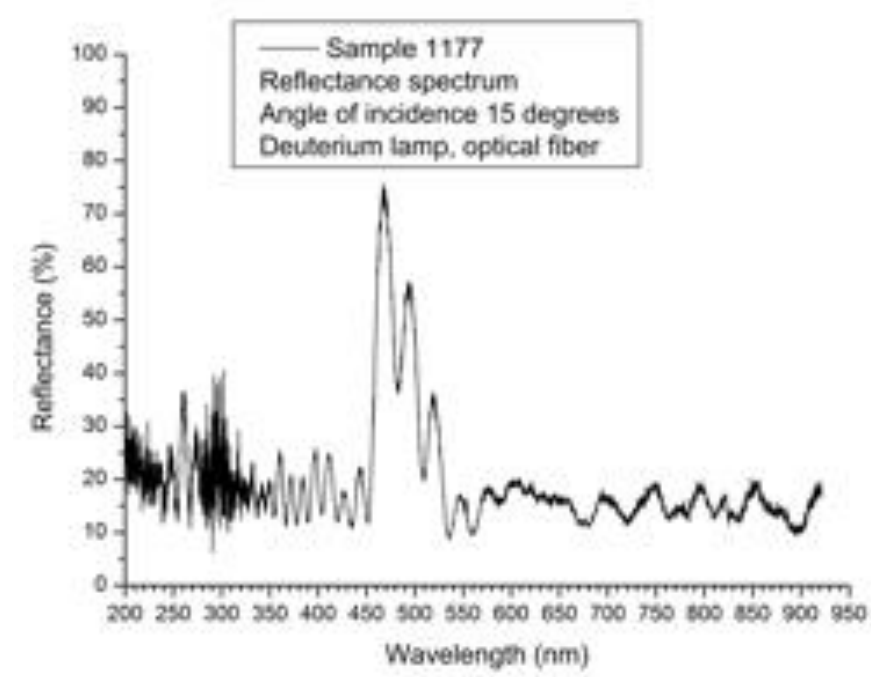

Для отработки роста гетероструктур $\mathrm{AlGaN}: \mathrm{Si}$ с брегговскими зеркалами была выращена структура с одним брегговским зеркалом с отражением $50 \%$. Гетороструктура состояла из буферного слоя AlN толщиной около 200нм, брегговского зеркала $\mathrm{Al}_{0,28} \mathrm{Ga}_{0,72} \mathrm{~N} / \mathrm{GaN}$ и активного слоя $\mathrm{Al}_{0,62} \mathrm{Ga}_{0,38} \mathrm{~N}: \mathrm{Si}$ толщиной 640нм. Рост буферного слоя AlN производился после процесса нитридизации, оптимизация условий которого позволяет выращивать слои AlN c гладкой морфологией поверхности без инверсионных доменов азотной полярности. Легирование активного слоя осуществлялось газовым источником с $0.7 \%$ силаном $\left(\mathrm{SiH}_{4}\right)$, разбавленным в азоте $\left(\mathrm{N}_{2}\right)$. Структура самого брегговского зеркала состояла из 16 периодов чередующихся слоёв $\mathrm{Al}_{0,28} \mathrm{Ga}_{0,72} \mathrm{~N} / \mathrm{GaN}$. Для измерения спектра отражения использовалась 30 -ваттная дейтериевая лампа. Фотолюминесценция (ФЛ) возбуждалась Не-Сd лазером (длина волны 325 нм) и 4-ой гармоникой импульсного Nd:YLF лазера (длина волны 263 нм, длительность импульсов 5 нс, частота повторений 1 кГц).

Измерение спектра отражения сформированного брэгговского зеркала путём засветки со стороны сапфировой подложки показало усиление 4, 3 и 2 раза для длин волн $475 \mathrm{Hм}, 500 \mathrm{Hм}, 525 \mathrm{нм}$ (см. Рисунок). При заданном содержании $\mathrm{Al}$ энергетическое положение максимума интенсивной полосы ФЛ составляет 500 нм, что соответствует зеленому спектральному диапазону. При возбуждении ФЛ с лицевой стороны данный образец продемонстрировал усиление излучения активного слоя на длине волны 500нм. 